\title{
Thucydides Philosophistoricus: The Way of Life of the Historian
}

\section{Tucídides, historiador-filósofo: la manera de vivir del historiador}

\author{
Panos Christodoulou ${ }^{1}$ \\ University of Cyprus (Chipre)
}

Recibido: 01-04-17

Aprobado: 15-04-17

\begin{abstract}
Although Thucydides does not shed light on the reasons and the historical facts relating to his departure from Athens, he is certainly far clearer on the effects that this event had on his work. He explicitly recognizes that the condition of exile offered him the rather unique possibility to observe the conflict from the Peloponnesian side as well and to follow the course of events

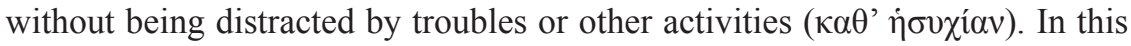
study I emit the hypothesis that in 5.26 Thucydides makes an indirect allusion to the fact that a life of quietude, which liberates the eminent thinker from engagement in political life, is the path leading to intellectual production. This reading can help us recognize the intellectual affinities between Thucydides and the Athenian thinkers of the end of the fifth century BC and more particularly with Socrates's circle.
\end{abstract}

Key-words: Exile, Intellectual, Tranquillity, Philosophers, Pericles.

\section{Resumen}

Aunque Tucídides no arroja luz sobre las razones ni sobre los hechos históricos relativos a su salida de Atenas, sí es de lejos más preciso acerca de las consecuencias que tal acontecimiento tuvo sobre su obra. Reconoce

\footnotetext{
${ }^{1}$ (panosavch@gmail.com) Scientific Collaborator of the Department of History and Archaeology of the University of Cyprus and Adjunct Lecturer at the Open University of Cyprus. He is also member of Anhima (UMR 8210, Anthropology and History of the Ancient World, University of Paris I Pantheon-Sorbonne). His main research concentrates on the study and analysis of political texts of the 5th and 4th centuries B.C. and he has published several articles related to the conception of leadership in Greek political thought of the Classical period.
} 
explícitamente que su condición de exiliado le ofreció la posibilidad más bien única de observar el conflicto desde el lado peloponesio, como también la de seguir el curso de los acontecimientos sin que los problemas u otras

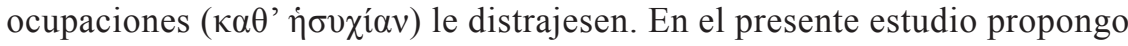
la hipótesis de que en 5.26 Tucídides alude indirectamente al hecho de que una vida tranquila, que libera al eminente pensador de todo compromiso con la vida política, constituye la vía que lleva hacia la producción intelectual. Tal lectura permite ayudarnos a reconocer las afinidades intelectuales entre Tucídides y los pensadores atenienses de finales del siglo $\mathrm{V}$ antes de nuestra era, y en especial con las del círculo socrático.

Palabras-clave: exilio, intelectual, tranquilidad, filósofos, Pericles.

"I lived through the whole of the war, studying it with mature perception and in the intellectual pursuit of an accurate understanding of events. The fact that I was in exile from my own country for twenty years after my command against Amphipolis gave me the opportunity to observe affairs on both sides, no less on that of the Peloponnesians, and to reflect on them with no distraction" 2

This passage which probably constitutes the only incontrovertible fact in Thucydides's biography ${ }^{3}$, has been much discussed. With the exception of Luciano Canfora who argued that Thucydides was back in Athens by 411 $\mathrm{BC}$ the great majority of commentators accepts the fact that the writer of the Peloponnesian War returned to Athens after the end of the war ${ }^{4}$. Although Thucydides does not shed light on the reasons and the historical facts relating to his exile $(\varphi v \gamma \eta)^{5}$ he is certainly far clearer on the effects that this event had on his work ${ }^{6}$. He explicitly recognizes that the condition of exile offered him the rather exceptional occasion to observe the conflict from the Peloponnesian side as well and to follow the course of events without being distracted by troubles

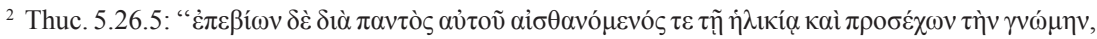

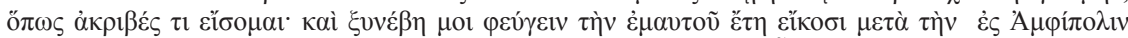

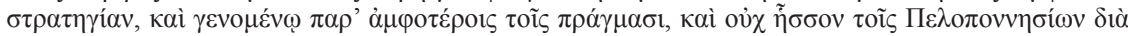

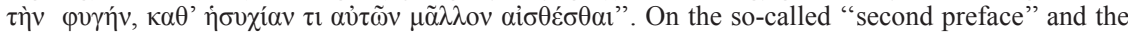
methodology of Thucydides see Schepens 1980: 168-197.

3 Canfora 2006: 11 .

${ }^{4}$ See Canfora 2006. Debidour 2008 follows Canfora and believes that Thucydides was in Athens in 411 B.C., a hypothesis which seems quite improbable.

5 On the ancient terminology see Gaertner 2007: 2: "the English word "exile" is far more precise than the corresponding Greek and Latin terms. Whereas the modern derivatives of the Latin word exilium imply an involuntary departure, sanctioned by political or judicial authorities, the ancient

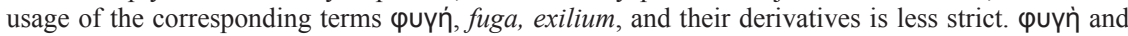
$\varphi \varepsilon u ́ \gamma \varepsilon I V$ cover both the expulsion of groups or individuals and their voluntary departure".

${ }^{6}$ On the figure of the exiled historian in antiquity see Payen 2010 and especially the fine analysis of Dillery 2007.
} 
or other activities ( $\left.\kappa \alpha \theta^{\prime} \dot{\eta} \sigma v \chi i \alpha v\right)$ "'7. As far as I know little attention has been given to the word $\dot{\gamma} \sigma \chi \chi i \alpha$ in this passage.

It is worth pointing out that from the end of the fifth century words such as $\dot{\sigma} \sigma 0 \chi i \alpha, \sigma \chi 0 \lambda \eta \dot{n}, \dot{\alpha} \pi \rho \alpha \gamma \mu \sigma \sigma u ́ v \eta$, were explicitly linked with the ideal of vita contemplativa and more precisely with the individual who is exclusively devoted to the act of writing a political, philosophical text ${ }^{8}$. In what follows I would like to consider the hypothesis that in 5.26 Thucydides does not present his exile "strictly form a methodological view, as offering an advantageous situation and providing him with the "leisure" to observe affairs more closely" . The historian makes also an indirect allusion to the fact that a life of quietude, which liberates the eminent thinker from engagement in political life, is the path leading to intellectual production. I hope to show that this reading can help us recognize the intellectual affinities between Thucydides and the Athenian thinkers of the end of the fifth century BC and more particularly with Socrates's circle.

\section{"To those who no longer have a homeland, writing becomes home" 10}

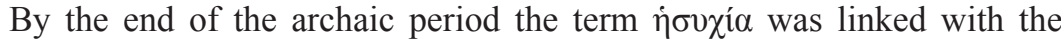
aristocratic ideal of leisure and tranquility which involved spending time in political life and especially on activities such as hunting and the symposia ${ }^{11}$. In the classical period, Herodotus suggests that $\dot{\sigma} \sigma \chi \chi \dot{\alpha} \alpha$ is sometimes a prerequisite for the deployment of rational thought ${ }^{12}$, and in Thucydides, were the the verb

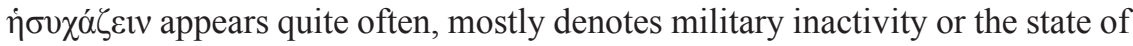
"neutrality" 13 .

However, the writer of the Peloponnesian War is probably the first thinker to develop rather systematically the idea that "tranquillity" allows us to deal more effectively with the stressful reality surrounding us. When he was under the pressure of the over-eager Athenians who wanted to sail immediately to Sicily, Nicias said that "he would prefer to deliberate with his colleagues

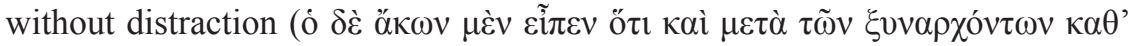

\footnotetext{
${ }^{7}$ I adopt here the suggestion of Gomme 1970 on 5.26.5, who translates $\kappa \alpha \theta$ ’ distracted by troubles or other activities".

${ }^{8}$ Demont 1990: 16-17, 279-282.

9 Schepens 2007: 48.

${ }_{10}$ Adorno 1974: 51.

11 On the aristocratic ideal of leisure see Demont 1990: 53-85, and especially Han Van Wees 2009.

12 See Demont 1990: 181-182 with examples.

13 See the examples given by Huart 1968: 368-369. Also as Zumbrunnen 2008: 36 convincingly argued "the keeping quiet that hesychia marks in fact does not amount to simple silence. It is more properly understood as a mode of action through inaction, one that often appears on the battlefield, either through the designs of commanders or through the force of circumstances".
} 


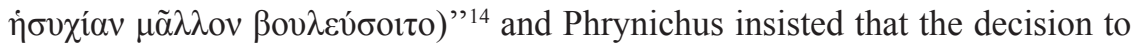
avoid a battle which seems unnecessary is not a sign of cowardice, because it is better to earn time and without distraction to be fully prepared for the

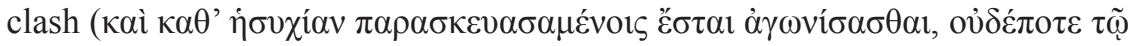

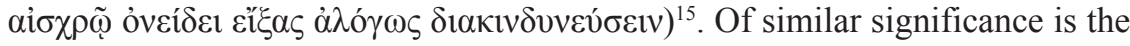
passage where the Melians responded to the Athenians that "the fairness of the proposal, that we shall at our leisure instruct one another ( $\dot{\eta} \mu \dot{\varepsilon} v \dot{\varepsilon} \pi \varepsilon \dot{\varepsilon} \kappa \varepsilon 1 \alpha$

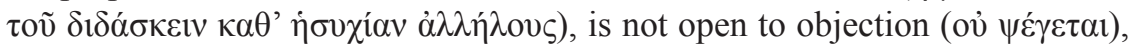
but these acts of war, which are not in the future, but already here at hand, are manifestly at variance with your suggestion" ${ }^{16}$. In other words, the delegates of Melos argue that we can instruct each other when we are not distracted by the war, when we have the opportunity to develop rational and well elaborated ideas, something that is impossible for the moment because we are in the "eye

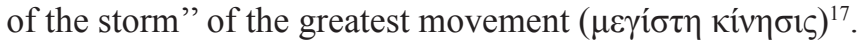

It comes as no surprise then that Thucydides deliberately insists that he was given the opportunity to observe without distraction the course of events only after having left the theatre of the war. In that context, the so called "second preface" is masterfully placed in this stage of the narrative. The historian indirectly illustrates the fact that his political activity, the devastating plague which afflicted Athens and of which he was not only an observer but also a victim $^{18}$, his engagement in military activities as strategos, and more generally his devotion to public affairs ${ }^{19}$ deprived him of rest and tranquillity, which are absolutely necessary for a full understanding of the causes and certainly the real dimensions of the war.

Although the exile of ancient historians and especially that of Thucydides has attracted its fair share of scholarly analysis, little attention has been paid to the notion of "inner exile" and more precisely that of "self-imposed exile", which I think can be applied in the case of the historian of the Peloponnesian War. Many literary critics recognize the category "inner exile" or "self-imposed exile" as a way of describing the alienation of a writer or artist from his native community or more generally from the community where he is living ${ }^{20}$.

14 Thucydides 6.25.2. Rogkotis 2006: 60 was perfectly right to stress the fact that in this scene Thucydides makes use of the so called "wise-adviser" or tragic "warner motif".

15 Thuc. 8.27.2. In this case Thucydides praises Phrynichus's intelligence. See Andrewes 1981 on 8.27.5. On Phrynichus see Heftner 2005.

16 Thuc. 5.86 .

17 Thuc. 1.1.2.

18 Thuc. 2.48.3.

19 Rhodes 2006: 523: "He [Thucydides] was undoubtedly an engaged Athenian".

20 See Tabori 1972: 31-32; Tucker 1991: xiii-ix; Said 2000: 137-149. For the different categories of exile in Ancient Greece see Wolf 2008 and especially Forsdyke 2005 with important bibliography. Forsdyke 2005: 144-2-4, uses also the term "inner exile" in order to describe the Athenian demos during the oligarchic revolution. For the exiled writers in Ancient Greece see Gaertner 2007. 
Lucian's famous passage on the characteristics of the excellent historian is a forcible reminder that this kind of exile is not a mere contemporary construction. According to the author " $\ldots$ the writer must be fearless, incorruptible, free, a friend of free expression and the truth, ... well-disposed to all men up to the point of not giving one side more than its due, in his books a stranger and a man

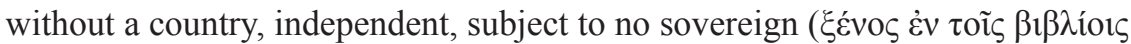

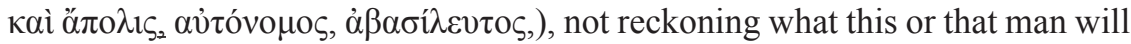
think, but stating the facts. Thucydides laid down this law very well..."21.

For Lucian it is impossible to envision the historian as a professor or a writer, as a pure theoretician whose authority derives directly from his excellent knowledge and use of a corpus of epistemological doctrines which can be considered as indispensable in order to narrate historical events in a masterly way. We must not forget that during Antiquity philosophy and more generally intellectual activity was never conceived as a systematic study of theoretical approaches and dogmatic accounts concerning life and human nature, but, as Pierre Hadot brilliantly showed, it was a way of life $e^{22}$. This is exactly what Lucian argues in this remarkable passage. Being a historian is an art of living ${ }^{23}$.

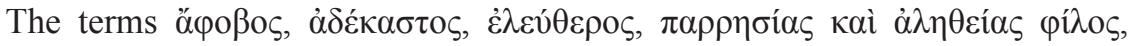

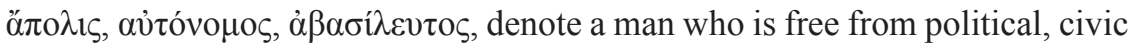
or even social restrictions and obligations and who adopts a specific way of life which permits him to preserve and protect his intellectual freedom and thus become an excellent historian. Apparently in his eyes Thucydides embodied this ideal more than any other writer and I think his approach contains a kernel of truth.

It is not unreasonable to support that Thucydides gives a new content to the term $\dot{\eta} \sigma 0 \chi i ́ \alpha$. In 5.26 tranquility is explicitly connected to a specific intellectual activity: reflection and undivided devotion to a major subject. The presentation of the greatest of the wars in written form ${ }^{24}$, is extremely relevant to the very fact that Thucydides was no more bound by civic obligations. He was without city, free from the sovereignty of the demos, master of his own destiny, independent, free to state the facts as they were. His identification as an Athenian a few lines before the "second preface" is significant ${ }^{25}$. Thucydides the Athenian

${ }^{21}$ Luc., Hist. Conscr. 41: “Toเõ̃

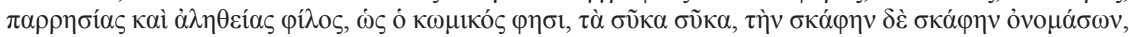

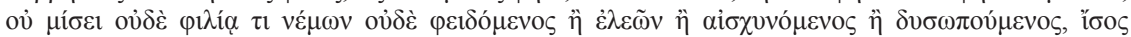

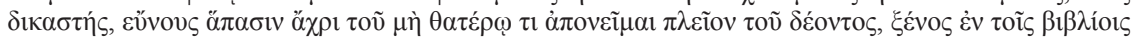

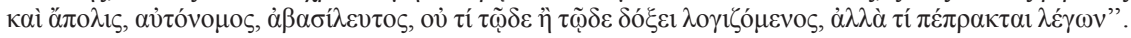
On Lucian and his relation to Thucydides's text see the recent study of Tamiolaki 2015.

${ }^{22}$ For this term in ancient Greek philosophy see Hadot 1995.

${ }^{23}$ We cannot analyse here the personality of Lucian and his place in Ancient literature. However, it is important to remember the profoundly philosophical aspect of his thought. See Longo 1964; Mestre 2012/13.

${ }^{24}$ Thuc. 1.21.2.

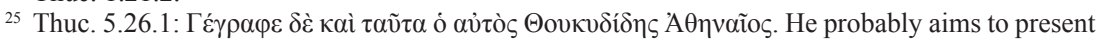


transformed his personal misfortune -the painful physical separation from his homeland where he had served as an active citizen- to a great intellectual achievement, something that apparently demands an inner transformation.

A complex question arises here: did exile make Thucydides a historian? This complicated issue exceeds the subject of the present article; I will however risk an outline of the answer that seems to me the correct one. Exile did nonmake Thucydides a historian. What made him a writer was his conscious decision to adopt a new, radically different way of life, which provided him with the necessary conditions to attain higher contemplative pursuits ${ }^{26}$. In 5.26 tranquillity is not an abstract notion or an aristocratic privilege, but a way of living, in the same way as is for his fellow citizens the unstoppable movement (kinesis), because they "have been born to allow quiet (ívхíav) neither to themselves nor to others" ${ }^{27}$. This is the ethos of the Athenians and this was also his own. There came a moment when he realised that in order to comprehend and write down the complexity of human nature and society, the intellectual must stand on a "no man's land". What is remarkable in 5.26 is that the author of the Peloponnesian War informs his reader that the man who is describing for the present and future generations the "greatest movement" is actually a man who manages to transform his unstoppable kinesis in the field of battle or in the Athenian political arena into an unstoppable intellectual kinesis.

In that context, if exile was not Thucydides' choice, the full and unconditional dedication to the composition of a written text that will be an everlasting possession, certainly was. Neither Themistokles, nor Cimon or Alcibiades -to mention but these prominent Athenians generals- made their banishment from Athens an occasion for change, an occasion to live in "quiet" and write down a great event. In other words, Thucydides's decision reflects the intellectual orientation of his personality, his ability to transform his insightful observation of human nature into a written monument.

Thucydides did not return to Athens until an amnesty was proclaimed in 404 BC. There is no doubt that a part of the Peloponnesian War was written during the years of his homecoming, when an extensive revision of his text began. Internal evidences indicate that some passages where written after the end of the war and it is beyond any doubt that the methodological preface

himself as the only one among his fellow citizens who can express freely his opinion about the war. It is important here to remark that parrhèsia, which according to Lucian is one of the virtues that the ideal historian must possess, is essentially philosophical. See the excellent comment of VisaOndarçuhu 2006: 276: "Les personnages auxquels Lucien attribue l'aptitude à la $\pi \alpha \rho \rho \eta \sigma i ́ \alpha$ sont essentiellement des philosophes".

${ }^{26}$ Dillery 2007, rightly argues that indeed exile did not make Thucydides a historian. He was already one at the outbreak of the War (Thuc. 1.1.1). Although Thucydides very clearly states that he started writing down the war from its very beginning, he admits however that it is just after the exile that he acquired extensive information from his own inquiry. It is after his departure from Athens that he formulated the idea that direct inquiry is the most reliable means for writing history. See Schepens 2007: 48.

27 Thuc. 1.70.8. 
5.26 was demonstrably composed after the fall of his native city ${ }^{28}$. We can then assume that Thucydides's fundamental ideological and methodological observations and statements about the benefits of thinking and writing without being "distracted by troubles or other activities" were perfectly crystalized when he returned to Athens. By then he was able to conceive his text in its entirety and to fully appreciate the particular conditions which helped him to perfect his methodology.

In light of these observations I would like to suggest that Thucydides's elaborate idea that the best way to accomplish his intellectual achievement was to retire from political life would profoundly mark the Athenian philosophers of the fourth century BC., and more precisely the disciples of Socrates and those influenced by his personality and teaching ${ }^{29}$. I am referring here to Plato, Isocrates and Xenophon, who form the most interesting and the most identifiable intellectual field in classical Athens.

\section{Thucydides's impact on the philosophes of the $4^{\text {th }}$ century BC}

Recent studies reveal the fact that we can no longer place Thucydides in a single intellectual trend ${ }^{30}$. During the classical period history was not considered to be an autonomous and distinct discipline ${ }^{31}$. Those to whom we refer as "historians" in the $5^{\text {th }}$ and $4^{\text {th }}$ centuries BC were not only insightful observes of historical events; they were also thinkers who were positively influenced by contemporary debates on politics and science ${ }^{32}$. Thucydides's interpretation of the "greatest of the wars", is based on theoretical assumptions that were current in his time, "and on ideas developed by philosophers, sophists and medical writers" 33 . His text constituted, amongst other things, an attempt to comprehend the complexity of human nature and the socio-political ethos of his contemporary societies. Through the narration of the words, actions and deeds of contemporary political groups and individuals Thucydides offered to his readers the possibility to acquire complex, rational and scientific political knowledge. From this point of view the philosophers of the $4^{\text {th }}$ century BC who were deeply interested in political history, were certainly engaged in dialogue with several aspects of the Peloponnesian War. We can imagine that in their eyes Thucydides was an eminent writer who developed a rather exceptional political discourse.

\footnotetext{
28 See Hornblower 2008: 50-53.

29 We can include Isocrates among those who were influenced by Socrates's personality. See Demont 2011.

${ }^{30}$ See Bertelli 1993: 69; Raaflaub 2002: 186. See also the very useful comments by Thomas 2006.

${ }^{31}$ Bouvier 1997: 49; Hartog 1999: 18 -19.

32 See Tsakmakis 2016.

33 Raaflaub 2002: 150.
} 
In the fifth century BC "what counted as wisdom was an extraordinarily open-ended and negotiable question. Anyone could set himself up as a philosopher or as a sophist or, come to that, as a doctor" 34 . In that context, differentiation of intellectual categories is problematic when applied to Thucydides's contemporaries. Greek intellectual activity is the history of polemic between those who claim the title of "wise" and "philosopher" 35 . Their fascinating effort to appropriate a specific prose genre (dialogues, political discourses, historical narratives, historical fictions, epideictic rhetoric etc.) in order to put forward their own world view, as well as their own political ideas derives, essentially, from a strategy of distinction ${ }^{36}$. More precisely, if indeed "Thucydides might have been surprised or annoyed if his contemporaries called him a historian" ${ }^{37}$, the same goes for Xenophon ${ }^{38}$ but also for Isocrates, who presented himself as a philosopher and his teaching as philosophy and certainly "might have been surprised or annoyed if his contemporaries called him orator" 39 .

I am not suggesting of course that the author of the Peloponnesian War was a "member" of Socrates's intellectual circle nor that he was a "philosopher". We have to remember however that the term philosophein and its cognates were never used systematically before the fourth century BC and when it was used designated "intellectual cultivation". If Thucydides suggests that all Athenians were virtually practicing philosophy it is because the term does not point to any specific group of thinkers. In fact, a special subgroup of intellectuals that had appropriated the title "philosophoi" never existed in Athens before Plato and Isocrates $^{40}$.

Actually, they were the first -with Xenophon of course- to use the term philosophy in order to denote and legitimize a new and unique intellectual practice ${ }^{41}$. However, for these thinkers, philosophy is not just a mode of discourse or a corpus of doctrines but "a way of living and thinking" identified with the exclusive and unconditional devotion to the art of writing down and communicating their own "wisdom".

\footnotetext{
${ }^{34}$ Lloyd 1997: 103 .

${ }^{35}$ On the polemic character of ancient Greek philosophy see Brunschwig 2003; Azoulay 2009.

${ }^{36}$ See further Engels 1998: 57; Christodoulou (forthcoming).

37 Tsakmakis and Tamiolaki 2013: ix.

${ }^{38}$ Brisson, Dorion 2004, 138: "le Socrate des Mémorables est un philosophe et Xénophon luimême fait également œuvre de philosophe en exposant, dans une œuvre à la fois riche et complexe, les multiples facettes de l'inépuisable utilité de Socrate. Enfin, il faut s'interroger sur le fait que la reproche suivant laquelle Xénophon n'est pas un philosophe n'avait jamais été formulée, semble-til, avant le début du XIXe siècle". It comes then as no surprise the fact that Diogenes Laertes 2.2.

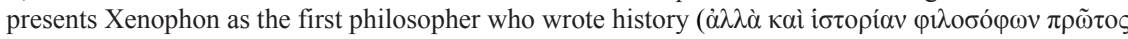
है $\gamma \rho \alpha \psi \varepsilon)$.

39 There is no need to further develop this point. See Eucken 1983; Nightingale 1995; Livingstone 2007; Azoulay 2009; Demont 2008; 2011; Christodoulou 2012; Christodoulou (forthcoming).

${ }^{40}$ See Malingrey 1961.

${ }^{41}$ See the useful comments of Nightingale 1995: 12-15.
} 
After the death of Socrates, Plato retired from political life and devoted himself to philosophy and writing. The foundation of the Academy (c. 387 BC) constitutes an innovative act which aimed to provide the philosopher with the opportunity to elaborate without distraction his political and philosophical ideas. It can also be seen as voluntary "exile" 42 . In an important passage of Anabasis Xenophon refers to his own exile ${ }^{43}$. Although he does not mention the reasons for his departure from Athens, he has more to say about what his life was during his deracination. For some years, he exercised military leadership and followed the campaigns of Cyrus the Young and of Agesilaus in Asia Minor.

It seems however that after his establishment in Peloponnese (c.390) ${ }^{44}$, Xenophon retreated from political and military active life. As Dillery observed "Xenophon finds a new identity in exile, as the patron and sole official of a new community he has founded" 45 . For around twenty years ${ }^{46}$, he apparently enjoyed the fruits of a peaceful, quite life, dedicated to noble activities and certainly to the most precious: The transformation of his experiences, his reflections, his political and philosophical ideas into written texts. Xenophon was a prolific writer and even though it is not an easy task to date his intellectual production, it is very probable that he composed part of his works after his return to Athens ${ }^{47}$, where we can imagine that he continued to observe as an "outsider" the words and acts of his fellow citizens, and more generally of the Greeks.

Isocrates who founded his philosophical school around 390 B.C. ${ }^{48}$ associated his intellectual activity with the composition of political discourses addressed to a reader audience ${ }^{49}$. According to his own words, after withdrawing from

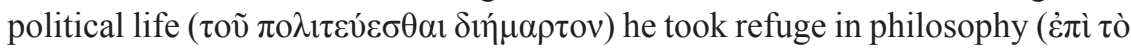

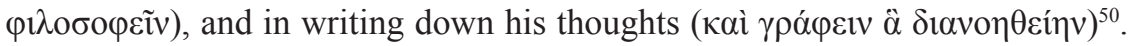
The word $\kappa \alpha \tau \varepsilon \dot{\varepsilon} \varphi \gamma o v$ reveals the very fact that he chose to be in a condition of

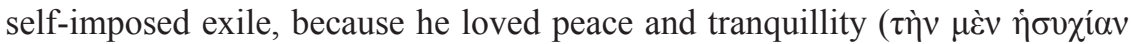

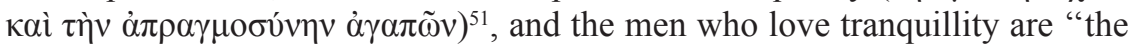
most unofficious and the most peaceable of all men who live in Athens ( $\alpha \lambda \lambda$ '

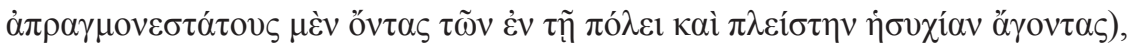

${ }^{42}$ See the excellent comments of Vegetti 2004. Also Azoulay 2007, with references to passages from Plato's work and especially Letter VII.

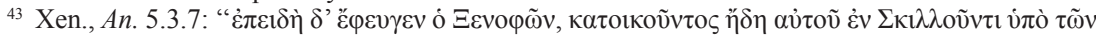

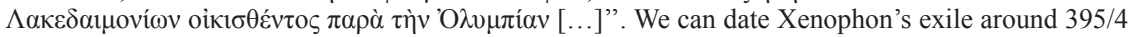
BC. For a full account of this matter see Tuplin 1987.

44 See Azoulay 2004: 13 with bibliography.

45 Dillery 2007: 67.

${ }^{46}$ Xenophon was probably forced to leave Scillus after Sparta's defeat at Leuctra (371 BC).

47 This is also a much-debated subject. See Badian 2004 who I think rightly argued that Xenophon returned to Athens where he spent his last years.

48 See Engels 2003.

49 Too 1995.

${ }^{50}$ Isoc., Panath. 11.

51 Isoc., Antid. 151. 
giving their minds to their own affairs and confining their intercourse to each

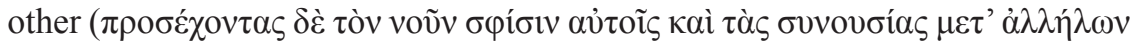
$\pi$ olov $\left.\mu \varepsilon^{\prime} \vee 0 v \varsigma\right) " 52$. This a remarkable passage. Isocrates's self-portrait is precisely that of a man who is not physically separated from his own country but is living in a condition of a self-imposed exile devoted to his intellectual production.

A great number of Athenian thinkers did not follow this path. Tragic and comedic poets, writers of forensic speeches, were present in the public sphere; they participated in the cultural and political life of their city, and never ceased to communicate to the Athenian demos aspects of their intellectual production ${ }^{53}$. This was not the case of thinkers such as Plato, Isocrates and Xenophon.

Disappointed by the tragic failures of the Athenian aristocrats to improve the Athenian politeia and after the execution of Socrates by the demos, they made the revolutionary decision on the one hand, to withdraw from political life, and on the other hand, not to engage in dialogue with the majority of their fellow citizens ${ }^{54}$. They never addressed the Athenian demos who profoundly ignored their theoretical, philosophical reflections. Thus, contrary to the traditional "intellectuals" and political leaders who subordinated their thought to action, being essentially judged on the results of their active engagement in political and public life, they elaborated the rather unique idea that it is much preferable to exercise politics through the force of thought and writing ${ }^{55}$.

Written after Thucydides's return to Athens, the so-called second preface could be seen as the statement of an eminent "member" of this small, highly educated community of thinkers who proclaimed their radically and unconditional "autonomisation" from the civic institutions. There is no question about the difficulty of speaking of a Thucydidean "intellectual milieu" ${ }^{56}$, but the very fact that Xenophon, Plato and Isocrates were extremely familiar with his oeuvre and his thought, could strengthen the hypothesis that the intellectual affinities between Thucydides's and Socrates's circle were more substantial than we may believe ${ }^{57}$. In particular, I suspect that the author of the Peloponnesian War was considered by the subsequent generation of Athenian thinkers as indeed one of the very first Athenian intellectuals to have adopted a "philosophical way of life" related to the activity of contemplating and writing.

\footnotetext{
${ }^{52}$ Isoc., Antid. 227.

53 See Humphreys 1978: 228.

54 See Ober 1998, and the fine analysis of Azoulay 2007.

55 Azoulay 2007: 184 was perfectly right when he observed that: "la politique reste en effet l'horizon dans lequel s'inscrivent presque tous ces penseurs, y compris les plus marginaux".

56 See Thomas 2006; Id. 2017.

57 See Hornblower 2009: 63, who observes that the relation of Thucydides to the Socratic corpus, has not been much studied. However, the book of Desclos 2003 is an excellent study on the influence that the work of Thucydides had on Plato. On Thucydides and Isocrates see Nicolai 2004 and on Thucydides and Xenophon see Canfora 1970.
} 


\section{Conclusion}

In the Athenian democracy the experts in public affairs did not have any autonomy of action and it was unthinkable that they could define the political principles of the community and maintain control of the institutions ${ }^{58}$. Indeed, the Athenian demos profoundly distrusted those who might have thought themselves irreplaceable. Thus, terms such as politike techne, politike episteme were excluded from the political terminology of the orators, who were perfectly aware of the fact that the demos was the sovereign of the city ${ }^{59}$. The Athenians citizens possessed the right not only to take an active part in political discussions, but also to make and follow the political decision which seemed to them the best.

It is unnecessary to enumerate here the "experts" who were victims of political trials, accused of failing to appropriately perform the tasks which the sovereign civic body entrusted to them. Condemned to be deprived of their political rights, to pay heavy punitive fines levied by the popular courts, driven into exile or even executed, the "experts" knew perfectly well that political activity entails a great risk. Thus, in the Athenian democracy, even the man who was equipped with superior intellectual and ethical principles and excellent political knowledge, was subject to the control of the majority which dominated the institutions and more generally the public sphere.

More than any other Athenian intellectual of the late fifth century Thucydides was not only fully aware of this dimension of politics, but if we have to believe his own testimony he was its "victim". In this context, his decision to withdraw from active political life constituted also a personal response to what he considered as a highly questionable way of administrating the city. Undoubtedly it is very significant that the first systematic reflection on political art and knowledge and more precisely on the figure of the political expert, is operated by Thucydides: he presented Pericles as an ideal leader functioning within a political system which was a "democracy only in name" ${ }^{\circ 0}$. In 2.65 Thucydides elaborates the idea that the Athenian political crisis appears in Athens when "the demos came to rule in fact as well as in name" ${ }^{\prime 61}$ or more precisely after the death of the men who embodied the virtues of the real statesman. Here we can wonder to what extent the focalisation on the personality of an eminent leader, his representation as the core of a political system which collapses after his death was not influenced by the Socratic idea

\footnotetext{
${ }^{58}$ On the extremely problematic place of the political expert in the Athenian democracy see Bertrand 2001: 932-942 and the recent, stimulating study of Ismard 2015.

59 Bertrand 2001: 930-940.

${ }^{60}$ Thuc. 2.65. We are not surprised by the fact that in the Athens of Thucydides's Pericles, one of the pylons of democracy collapses: isegoria. See further Christodoulou 2013. On Thucydides's description of the ability of Pericles to control the demos see Tsakmakis 2006.

${ }^{61}$ Ober 1998: 10; Christodoulou 2013: 246.
} 
that in order to establish an ideal form of government, the personality of the excellent political expert is far more important than the institutions.

The exact nature and characteristics of the audience of Thucydides can hardly be defined. However, we may formulate the hypotheses that he wrote for a well-educated reading audience able to appreciate the complexity and innovative approach of his narration. From Thucydides's own standpoint the true nature of his work can thus be appreciated only by a very restricted audience, by those educated men who were quite familiar with a literature focused on politics, forensic speeches, science treatises, constitutions, ideal forms of government, and other politico-philosophical issues. It is very probable that it was within this "microcosm of intellectuals", whose members were not exclusively Athenian, that the written text of Thucydides firstly circulated and became a valuable possession for Plato, Xenophon and Isocrates. It is also very probable that it is for the members of this community of intellectuals that the encomium of Pericles in 2.65 -which Thucydides wrote after the end of the war-, was composed. Following a particular intellectual trend of his time Thucydides tried, using the historical observation of Pericles's personality, to participate in a contemporary ideological and political debate concerning the ideal leadership, a subject which profoundly concerned Socrates and his disciples.

At the end of his work, Thucydides makes the much-discussed statement that during the first period of the new regime of the Five Thousand the Athenians appear to have had a better government than ever before, at least in his time t $^{62}$. As I have observed elsewhere, his testimony must be completely honest ${ }^{63}$. The way he has presented Pericles's leadership and Pericles's "democracy" to the reader does not constitute historical reality ${ }^{64}$. It is rather a theoretical reflection on the politeia, in particular a literary representation of the ideal relationship between the charismatic leader, the constitution and the citizens. Taking as his vantage point the action of an important historical figure, he represents in an extremely original manner an exceptional political expert.

I think that the peculiar, ahistorical and particular representation of Pericles by Thucydides is extremely relevant to a specific intellectual phenomenon: the development - mainly after the end of the Peloponnesian war- of the idea that formation of excellent political thought could be attained through the systematic study and representation of an ideal model of leadership.

The reflection on political expertise in the classical period flourishes within a community of intellectuals who profoundly believed that there was no place for them in public affairs. Situated at the margins of the civic community,

62 Thuc. 8.97: "And during the first period the Athenians appear to have enjoyed the best

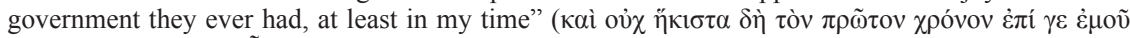

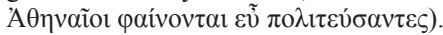

${ }^{63}$ Christodoulou 2013: 253-254.

${ }^{64}$ See also Will 2016: 70.

Araucaria. Revista Iberoamericana de Filosofía, Política y Humanidades, año 19, n ${ }^{\circ} 37$. Primer semestre de 2017. Pp. 151-167. ISSN 1575-6823 e-ISSN 2340-2199 doi: 10.12795/araucaria.2017.i37.07 
Plato, Isocrates and Xenophon elaborated major political projects based on the innovative and singular idea that political power must be the exclusive privilege of the man who perfectly masters the art of government. It is thus remarkable that this idea was systematically and dynamically developed in political treatises such as The Republic and the Statesman of Plato, the Cypriot Orations of Isocrates and the Cyropaedia and the Agesilaus of Xenophon, all composed during the first half of the 4th century $\mathrm{BC}$, and more precisely, between the years 380 and 355. In these texts, the coexistence of power and knowledge are considered absolutely necessary for the advent of the perfect political expert who will break the infernal cycle of political instability. Certainly, there was no place for these men in the Athenian democracy ${ }^{65}$. This, I think, was the greatest lesson given to them by the way of life and the intellectual production of Thucydides the Athenian.

${ }^{65}$ For a more detailed analysis see Christodoulou (forthcoming). 


\section{Bibliography}

Adorno 1974: T. Adorno Minima Moralia: Reflections on a Damaged Life (London, 1974).

Andrewes 1981: A. Andrewes, A Historical Commentary on Thucydides, V: Book 8 (Oxford, 1981).

Azoulay 2004: V. Azoulay, Xénophon et les Grâce du pouvoir. De la charis au charisme (Paris, 2004).

Azoulay 2007: V. Azoulay, Champ intellectuel athénien et stratégies de distinction dans la première moitié du IVe siècle: de Socrate à Isocrate [in J.-C. Couvenhes, S. Milanezi, eds.: Individus, groupes et politique à Athènes de Solon à Mithridate, Tours, 2007], pp. 171-199.

Azoulay 2009: V. Azoulay, Une éloquence de combat : querelles intellectuelles et appel à la violence chez Isocrate [in V. Azoulay, P. Boucheron, eds: Le mot qui tue. Les violences intellectuelles de l'antiquité à nos jours, Paris, 2009], pp. 303-321.

Bertelli 1993: L. Bertelli, Modelli constituzionali e analisi politica prima di Platone [in P. Donnini, ed.: Filosofia, Politica, Retorica, intersezioni possibili, Torino, 1993], pp. 27-48.

Bertrand 2001: J.-M. Bertrand, Réflexions sur l'expertise politique en Grèce ancienne, "Revue historique", 306.4 (2001), pp. 929-964.

Bouvier 1997: D. Bouvier, Mythe où histoire: le choix de Platon. Refléxions sur les relations entre historiens et philosophes dans l'Athènes classique [in M. Guglielmo, G.F. Gianotti, eds.: Filosofia, Storia e Immaginario mitologico, Alessandria, 1997], pp. 41-64.

Brisson, Dorion 2004: L. Brisson, L.-A. Dorion, Pour une relecture des écrits socratiques de Xénophon, "Les Études philosophiques", 69.2. (2004), pp. 137-140.

Canfora 1970: L. Canfora, Tucidide continuato (Padova, 1970).

Canfora 2006: L. Canfora, Biographical Obscurities and Problems of Composition [in Rengakos, Tsakmakis 2006], pp. 3-32.

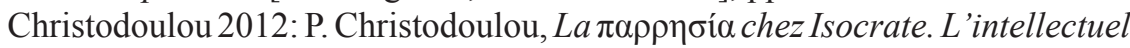
et la liberté de parole dans l'Athènes du IVe s. av. J.-C., "Tekmêria”, 11 (2012), pp. 89-114.

Christodoulou 2013: P. Christodoulou, Thucydides' Pericles. Between Historical Reality and Literary Representation [in Tsakmakis, Tamiolaki 2013], pp. 225-257.

Christodoulou (forthcoming): P. Christodoulou, Philosophie et pouvoir dans la pensée d'Isocrate et de Platon. Le règne de l'expert politique [in $\mathrm{P}$. Christodoulou, S. Wackenier, eds.: De l'oralité à l'écriture. Etudes offertes à J.-M. Bertrand, "Cahiers du Centre Gustave Glotz" (forthcoming). 
Debidour 2008: M. Debidour, De l'exclusion à l'exil dans le monde grec et d'un exilé célèbre en particulier [in C. Wolff, ed.: Exclus dans l'Antiquité, Actes du colloque organisé à Lyon les 23-24 septembre 2004, Paris, 2008], pp.37-56.

Demont1990: P. Demont, La cité grecque archaïque et classique et l'idéal de la tranquillité (Paris, 1990).

Demont 2008: P. Demont, Isocrate et le Gorgias de Platon, "L'information littéraire", 60.2 (2008), pp. 3-9.

Demont 2011: P. Demont, Y a-t-il une science du politique? Les débats athéniens de l'époque classique [in J. Jouanna, M. Fartzoff, B. Bakhouche, ed.: L'Homme et la Science, Actes du XVIe Congrès international de l'Association Guillaume Budé, Paris, 2011], pp.183-193.

Dillery 2007: J. Dillery, Exile: The Making of the Greek Historian [in Gaertner 2007], pp. 51-70.

Desclos 2003: M.-L. Desclos, Aux marges des dialogues de Platon, Grenoble, 2003.

Engels 2003: J. Engels, Antike Überlieferungen über die Schüler des Isokrates [in W. Orth, ed.: Isokrates - Neue Ansätze zur Bewertung eines politischen Schriftstellers, Trèves, 2003], pp. 175-194.

Eucken 1983: Chr. Eucken, Isokrates, seine Positionen inder Auseinandersetzung mit den zeitgenössischen Philosophen (Berlin-New York, 1983).

Forsdyke 2005: S. Forsdyke, Exile, Ostracism, and Democracy: the Politics of Expulsion in Ancient Greece (Princeton, 2005).

Gaertner 2007: J.F. Gaertner, ed.: Writing Exile: the Discourse of Displacement in Greco-Roman Antiquity and Beyond (Leiden, 2007).

Gaertner 2007: J.F. Gaertner, The Discourse of Displacement in Greco-Roman Antiquity [in Gaertner 2007], pp. 1-20.

Gomme 1970: A.W. Gomme, A Historical Commentary on Thucydides, IV: Books 5.25-7 (Oxford, 1970).

Hadot 1995: P. Hadot, Philosophy as a Way of Life (Cambridge, Mass., 1995).

Heftner 2005: H. Heftner, Phrynichos Stratonidou Deiradiotes als Politiker und Symbolfigur der Oligarchern von 411 v.Chr. [in U. Bultrighini, ed.: Democrazia e antidemocrazia nel mondo greco, Atti del convegno internazionale di studi, Chieti 9-11 aprile 2003, Alessandria, 2007], pp. 89-108.

Hornblower 2008: S. Hornblower, A Commentary on Thucydides, III: Books 5.25-8.109 (Oxford, 2008).

Hornblower 2009: S. Hornblower Intellectual Affinities [in S.J. Rusten, ed.: Thucydides. Oxford Readings in Classical Studies, Oxford, 2009], pp. 6088 . 
Huart 1968: P. Huart, Le vocabulaire de l'analyse psychologique dans l'œuvre de Thucydide (Paris, 1968).

Humphreys 1978: S.C. Humphreys, Anthropology and the Greeks (London, 1978).

Ismard 2015: P. Ismard, La Démocratie contre les experts. Les esclaves publics en Grèce ancienne (Paris, 2015).

Lloyd 1997: G.E.R. Lloyd, The Revolutions of Wisdom. Studies in the Origins and Development of Early Greek science (Berkeley, 1997).

Livingstone 2007: N. Livingstone, Writing Politics: Isocrates' Rhetoric of Philosophy Rhetorica, "A Journal of the History of Rhetoric", 25.1 (2007), pp.15-34.

Longo 1964: V. Longo, Luciano e l'Ermotimo (Genova, 1964).

Mestre 2012/3: F. Mestre, Lucien, les philosophes et les philosophies, "Ítaca. Quaderns Catalans de Cultura Clàssica”, 28-29 (2012-2013), pp. 63-82.

Malingrey 1961: A.-M. Malingrey, Philosophia. Étude d'un groupe de mots dans la littérature grecque des Présocratiques au IVe siècle apr. J.-C. (Paris, 1961).

Nicolai 2004: R. Nicolai, Studi su Isocrate: la comunicazione letteraria nel IV sec. a.C. e i nuovi generi della prosa (Roma, 2004).

Nightingale 1995: A. W. Nightingale Genres in Dialogue. Plato and the Construct of Philosophy (Cambridge, 1995).

Ober 1998: J. Ober, Political Dissent in Democratic Athens (Princeton, N.J., 1998).

Payen 2010: P. Payen, Les historiens grecs entre la cité et l'exil, "Incidenza dell'antico", 8 (2010), pp. 11-37.

Raaflaub 2002: K. Raaflaub, Philosophy, Science, Politics: Herodotus and the Intellectual Trends of his Time [in E. J. Bakker, I.J.F. De Jong, H. van Wees, eds.: Brill's Companion to Herodotus, Leiden, 2002], pp. 149-186.

Rengakos, Tsakmakis 2006: A. Rengakos, A. Tsakmakis, eds.: Brill's Companion to Thucydides (Leiden-Boston, 2006).

Rhodes 2006: P.J. Rhodes, Thucydides and Athenian History [in Rengakos, Tsakmakis 2006], pp. 523-546.

Tucker 1991: M. Tucker, Introduction [in M. Tucker, ed.: Literary Exile in the Twentieth Century: An Analysis and Biographical Dictionary, Westport, $1991]$.

Rogkotis 2006: Z. Rogkotis, Thucydides and Herodotus: Aspects of Their Intertextual Relationship [in Rengakos, Tsakmakis 2006], pp. 57-86.

Saïd (2000): E. Saïd, Reflections on Exile and Other Essays (Cambridge, Mass., 2000).

Schepens 1980: G. Schepens, L' 'autopsie' dans la méthode des historiens grecs du Ve siècle avant J.C. (Brussel, 1980). 
Schepens 2007: G. Schepens, History and Historia: Inquiry in the Greek Historians [in J. Marincola, ed.: A Companion to Greek and Roman Historiography, I-II, Malden, 2007], pp. 39-55.

Tabori 1972: P. Tabori, The Anatomy of Exile: A Semantic and Historical Study (London, 1972).

Tamiolaki 2015: M. Tamiolaki, Satire and Historiography, "Mnemosyne", 68.6 (2015), pp. 917-936.

Thomas 2006: R. Thomas, Thucydides'Intellectual Milieu and the Plague [in Rengakos, Tsakmakis 2006], pp. 87-108.

Thomas 2017: R. Thomas, Thucydides and His Intellectual Milieu [in R. Balot, S. Forsdyke, E. Foster (eds.): The Oxford Handbook of Thucydides, Oxford, 2017], pp. 567-586.

Too 1995: Y. L. Too, The Rhetoric of Identity. Text, Power, Pedagogy (Cambridge 1995).

Tsakmakis 2006: A. Tsakmakis, Leaders, Crowds, and the Power of the Image: Political Communication in Thucydides [in Rengakos, Tsakmakis 2006], pp. 161-187.

Tsakmakis, Tamiolaki 2013: A. Tsakmakis, M. Tamiolaki, eds.: Thucydides Between History and Literature (Berlin-Boston, 2013).

Tsakmakis, Tamiolaki 2013: A. Tsakmakis, M. Tamiolaki, Introduction [in Tsakmakis, Tamiolaki 2013], pp. IX-XV.

Tsakmakis 2016: A. Tsakmakis, Historiography and Biography [in M. Hose, D. Schenker, eds.: A Companion to Greek Literature, Willey Blackwell, 2016], pp. 217-234.

Tuplin 1987: C.J. Tuplin, Xenophon's exile again [in M. Whitby, ed.: Homo Viator: Classical Essays for John Bramble, Bristol, 1987], pp. 59-68.

Zumbrunnen 2010: J. Zumbrunnen, Silence and Democracy: Athenian Politics in Thucydides' History (Penn, 2010).

Vegetti 2004: M. Vegetti, Filosofia e politica: le avventure dell'Accademia [in F. L. Lisi, ed.: The Ways of life in Classical Political Philosophy, Sankt Augustin, 2004], pp. 69-81.

Visa-Ondarçuhu 2006: V. Visa-Ondarçuhu, La notion de parrhèsia chez Lucien, "Pallas", 72 (2006), pp. 261-278.

Will 2016: W. Will, Democracy without an Alternative: Thucydides, Sparta, and Athens [in R. Thauer, C. Wendt, eds.: Thucydides and Political Order Lessons of Governance and the History of the Peloponnesian War, New York, 2016], pp. 55-74. 
